\title{
THE MYTHOLOGEM OF THE MOON IN THE POETRY \\ OF THE UKRAINIAN LITERARY PERFORMANCE GROUP BU-BA-BU
}

\author{
Tetiana Tsepkalo \\ $\mathrm{PhD}$, Lecturer, Kherson State University, Ukraine \\ e-mail: tanuysya@ukr.net, orcid.org/0000-0003-2690-3390
}

\section{Summary}

The article analyses the poetry of Ukrainian writers Yuriy Andrukhovych, Oleksandr Irvanets and Viktor Neborak using the mythopoetic methodology. The archetypal image of the moon and the specifics of its development in the poetic works of artists are considered in detail. The relationship of the mythology of the moon with traditional Slavic beliefs and ideas and the influence of world cultural heritage on its artistic realization are established. The works of these artists contain elements of the collective unconscious, consisting in the use of individual images in line with the ancient world-view, which can be decoded only at the subtext level. The meaning of this symbol for creating an artistic world-view is determined. Views of Yurii Andrukhovych, Oleksandr Irvanets and Viktor Neborak are studied on the world structure are studied through the decoding of the author's intentions in the interpretation of the archetypal image of the moon. The author's individual mythopoeia based on the astral image in the lyrics of the literary performance group $\mathrm{Bu}-\mathrm{Ba}-\mathrm{Bu}$ is studied.

Keywords: mythopoetics, worldview, artistic picture of the world, archetypal image, symbol, postmodernism.

DOI: https://doi.org/10.23856/4012

\section{Introduction}

The recipient's perception and understanding of the poetic image results from the decoding of symbolic meanings, allegories, allusions, subtexts, and the like. The mythologem, as the smallest unit of myth, expresses the partial meaning of the archetype and carries the reflection of mythological views and ancient beliefs. The literary studies frequently equate the above categories as their main function is to reflect the world-view continuum of different times and peoples. Mythologems can be common cultural and ethnic, expressing the mental peculiarities and traditions of the people, and, therefore, are closely associated with folklore.

The poetic work of the Eightiers, which include artists of the literary performance group Bu-Ba-Bu, was studied by Nina Anisimova, Iryna Borysiuk, Hryhorii Hrabovych, Tamara Hundorova, Nila Zborovska, Mykhailo Ilnytskyi, Victoria Kopytsia, Yanina Kulinska, Viktor Morenets, Natalia Filonenko, Roxana Kharchuk, Olena Chertkova, etc. Literary scholars emphasize the mytho-ritual and philosophical basis of the world-view positions of the period' artists, the profound metaphorical nature of their lyrics, the abandonment of rustic motives and socialist dogmas, etc. Nina Anisimova argues: "A decisive impetus for distancing from political prejudice prompted the poetic generation of the 1980s to find the artistic and philosophical aspects of the world-view in folklore and mythology, to transform traditional motives and images, to make the national primordial sources based on pagan-Christian syncretism relevant again" (Anisimova, 2012: 306).

The objective of our study is to analyse the nature and ways of functioning of the mythologem of the moon in the poetry of the literary group $B u-B a-B u$, the revelaing of the peculiaritie 
of the autho's interpretation of the lunar image and individual mythopoeia of Yurii Andrukhovych, Oleksandr Irvanets and Viktor Neborak. This objective requires that the following tasks are performed: finding lunar images in the poetic texts of these artists, analysing the modifications of the mythologem of the night orb in the poetry of the literary group Bu-Ba-Bu, ascertaining the influence on the formation of the author's world-view of ancient Slavic beliefs and world cultural heritage.

\section{Modifications of the archetypal image of the night orb in the poetry of Yurii Andrukhovych}

The denial of the aesthetics of socialist realism in the literature of the 1980s and the departure from ideological pressure caused the renewal and reconstruction of the traditional Ukrainian world-view in the poetic texts of the artists of the literary group $\mathrm{Bu}-\mathrm{Ba}-\mathrm{Bu}$. The development of postmodernism led to a rethinking of ideological and artistic principles, the liberation of national consciousness and culture. Thus, the Y. Andrukhovych's poem, "Observation of the Lonely" from his collection "Exotic Birds and Plants" is a reaction to the totalitarian regime: "Meanwhile, the county is full of all other rag / the squares are trampled in the holiday mornings / ladies walk the track as if though they're in France / where there's the hospital and school for the toffish ones / besides, no one assessed whether the Moon is close / the flag on the county tower faded away and dried / all the policemen look like basilisks / where both the church and the casino are for bald ones / besides, no one knows how close is Lviv / postal carriages pass by, all enlightened by prides / a hungry crowd flows, all sad, hundred-headed / how many are stingy and dumb here in fact / indeed, there are many under the halo, as well / dispersing their teachings with their talk traps opened / plus, the late clock has annoyed everyone / what is the real number of the blind and dumb / how many are those that could fly, by the way/ but no, they sit in the wineries, neither being the former nor latter / in the thoughtful Sodom of the lickerish and bellied / how many imprisoned are white, shiny and saints / because the local memory is fading within me/the night where I wander is bottomless / it does not glow but its shirt's sleeves do/ white, starched, restrained one" (Andrukhovich, 1991: 60). The epigraph to this poem is important to analyse it: "There were 16 blind, 7 deaf, 1 insane, 2 underdeveloped" A. Sharlovsky. Stanislaviv and Stanislaviv District. Statistics reference book. 1887. The quote taken from the historical source directs the reader to perceive the poetic text literally, because its very first line continues the reflection on the district. In our opinion, the author uses burlesque writing to reveal the veiled flaws of the society's situation. According to Natalia Filonenko, $\mathrm{Yu}$. Andrukhovych is capable of "presenting himself as a conquistador of Ukrainian figurative and artistic thinking, able to resolutely reject and get rid of the usual, trivial and bland forms and, instead, offer a new quality and paradigm of the mental routine" (Filonenko, 2007: 17). The late nineteenth century's Stanislav is a projection of Ivano-Frankivsk of the 1980s. The poet resorts to an allusion to point to the mess in the country, to the dominance of such social phenomena as corruption, drinking, poverty, beggary, etc. He uses the image of basilisk-like policemen to reveal the brutality of government agencies. Basilisks are mythical terrifying reptiles possessing supernatural power to kill with poison, gaze, and breath (Meletinsky, 1998: 116). The collective image of a hungry hundred-headed crowd is an allusion to the social situation of the people. The blind and dumb are all those who hold an inactive and passive position. Yu. Andrukhovich describes allegorically artists a, those who could fly, but sit in wineries. At the subtext level, there is an allusion to the lack of freedom of speech and creativity. The image of the Moon reinforces the ignorance of society. It is worth mentioning that this poem employs carnivalisation, 
as the amassing of peculiar masks allows concealing your attitude to totalitarian reality. Nina Anisimova notes: "An important component of the modernist world-view of the representatives of the poetic generation of the 1980s is the tendency to the aesthetics of play and absurdity, which made it possible to create an alternative "artistic reality" qualitatively different from the "realistic" one" (Anisimova, 2012: 306). Thus, in the poetic space of Yu. Andrukhovych, there is a shift in the categories of time and memory. The chronotope is focused around "hereand-now" events, that is, in the same place within the same night. The night is characterized as bottomless, that is, endless, which is provoked by the transient human memory. As the title of this work suggests, it is possible to assert the existence of an existential state of loneliness. This loneliness is manifested at the level of the character's observations of other residents and his distancing from the indifference that swept the whole city. Thus, the nationally conscious character in the poem "Observation of the Lonely" is associated with the insane, which indicates the presence of grotesque elements in the text.

\section{The peculiarity of the mythologem of the Moon in the lyric poetry of Oleksandr Irvanets}

The creativity of the $\mathrm{Bu}-\mathrm{Ba}-\mathrm{Bu}$ literary group is marked by the irrational perception of the world, visual effects, the synaesthesia of sensations, the projection of existence to the outer space, the striving for freedom of creativity, the chronotopic shift, the subjective sense of time, etc. Thus apprehension of the category of time is also found in the lyrical work of "bu-ba-bist" O. Irvanets "Reflection on the Run": "Well, farewell, time will tell. / As time and conscience are righteous arbitrators. / No longer figuratively, again/ But literally, I need to run like hell" (Irvanets, 1991: 28). The poet claims that separation from a loved one erases unpleasant moments of relationships from memory, because the feeling of loss is stronger than minor insults. M. Eliade notes that "the course of time implies an increasing distancing from the "beginning", and, consequently, the loss of primary perfection. Everything that happens in time is destroyed, disintegrates, degenerates, and eventually perishes" (Eliade, 1996: 59). Thus, the run of the character symbolizes an escape from the past and the quest for a happy future in spite of obstacles: "The time has come, I went to run. / For whom the road is paved? / I' $m$ in a good shape, Ineed no grace, / I'm balancing on the very edge. / It threw a traffic light at me / An insane band of cars and buses, / Well, I almost turned them over! / My run's a mix of break and bullfight. $<\ldots>$ ". (Irvanets, 1991: 28). Obstacles on a man's path point to life's troubles, which are easily overcome by a purposeful individual. The road is "a place of testing of human spiritual and physical forces, human ability both to create Good and to resist Evil, and the ability not to succumb to temptations and not to back down from danger" (Bagniuk, 2010: 365). The riskiness of the character's actions is evidenced by the absence of night orbs in the sky and the limited time both prompting him to decisiveness: "No moon or stars above, / The clouds filled the sky, / But I'm already running out to the bridge, / I have two minutes left before the diesel train departure..." (Irvanets, 1991: 28). According to A. Bagniuk, darkness is a symbol of a negative element, the concentration of the destructive energy of Chaos (Bagniuk, 2010: 346-347). The opposition of the character to all troubles is reinforced by the mythologem of the bridge, which is a symbol of "the connection between two opposites, the transition from the old to the new" (Bagniuk, 2010: 369). The context of the poem suggests that the bridge is a mediator between the past and the future. Thus, the main chronotopic loci appear in three-dimensional space. Natalia Filonenko, considering the time frame of O. Irvanets' poetry, notes: "The author is invariably interested only in the present, as fresh as possible one, so, his poems are often an 
emotional reaction to what is happening, not to what has already ended and been thought over. Thus, $\mathrm{O}$. Irvanets is a poet of the present day, and his constant interest in social processes causes the appearance of topical texts, which, however, remain relevant and understandable decades later" (Filonenko, 2007: 183). Consequently, the artistic chronotope in the mythopoetic picture of the artist's world is shifted and acquires mythological significance.

\section{The mythosemantics of the lunar image in the poems of Viktor Neborak}

The appeal to the images of public transport is observed in all artists of the 1980s, which is due to their reaction to the scientific and technological progress of society. Thus, the symbolism of the night tram is found in the poetry 'Melody' from the collection "Amber Time" by $\mathrm{V}$. Neborak, one of the members of the $\mathrm{Bu}-\mathrm{Ba}-\mathrm{Bu}$ literary group: "Autumn shakes the golden bell. / Solitude... tears of separation... / The only escape from autumnal torments/ is night tram and the Moon catching it up. // But where? You crushed it all long ago. / And memory is like leaves on water. / A passenger confused. IA driver dumb. / The stops. This one's not mine. Not mine. // Darkens the world of the confused, / it spins the roads at random. / And here I am-a disappointed baby. / And all of a sudden, you're nowhere. // Dispersed between the autumn ruins, / through ice, in which the time extinguishes the stars, / fly into the silent absence of us - /the night tram and Moon to catch it up" (Neborak, 1987: 49). The night tram is perceived by the character as a shelter from the sufferings of autumn and solitude. G. Bashlyar believes that such a shelter is motivated by subconscious impulses of the individual: "The centres of boredom, loneliness, dreams merge into an oneric home, more durable than the scattered memories in the home" (Bashlyar, 2004: 36). Memory is compared to leaves on water. Such an image is associated with impermanence, temporality, transience. Thus, we can assume that the character seeks to forget certain moments of his life, but subconsciously continues to think about someone close to him. We find an explanation of this phenomenon in the anthropological theory of Claude Lévi-Strauss: "After all, the subconscious, this repository of memories and images accumulated by everyone during their lives, becomes simply one of the aspects of memory; while the subconscious asserts its non-transitory character, it also places its limitations, since the term "subconscious" is marked by the fact that it is not always possible to evoke memories, although they persist" (Lévi-Strauss, 2000: 193). Time brings on oblivion, even endowed with the ability to extinguish the stars, but the main character keeps memories on the surface of consciousness like leaves on water. "It is critical to keep in mind even the smallest details of existence (present or previous), because only these memories manage to 'burn' one's past, seize it, prevent it from affecting the present”, M. Eliade believes (Eliade, 1996: 95). The poem implicitly reveals the motif of the course of life in the image of stars fading away. According to A. Bagniuk, the star affects the fate of "its' person, and this is known as a "destiny" (Bagniuk, 2010: 346). That is why the disappearance of the astral orb from the sky is associated with the end of life. The Moon is associated with feelings, irrationality, subconsciousness (O'Connell, Airey, 2009: 120). Thus, at the subtextual level, the author argues that a person finds salvation from suffering in himself. The last lines endow the lunar image with the symbols of eternity along with the discreteness of human existence. The imaginary movement of the night orb, which accompanies the character during his ride in the tram, testifies to the cosmic thinking of the poem's author. Identifying the peculiarities of the individual style of V. Neborak, Natalia Filonenko draws attention to the thematic homogeneity of his poetry: "Throughout his creative heritage, which covers a quarter of a century, he has been concerned with the same issues: the meaning of human existence, the content of the concepts of happiness and misfortune, soul-searching and quest for his place in 
life" (Filonenko, 2007: 10). Thus, the urban motives of the analysed poetic text testify to the individual author's mythological thinking.

\section{Conclusions}

The analysis of the mythologem of the moon in the poetry of the $\mathrm{Bu}-\mathrm{Ba}-\mathrm{Bu}$ literary group allows distinguishing the following peculiarities of their creativity: the reactivation of traditional beliefs and ideas of the people, the implementation of mytho-ritual models, chronotopic parameterisation, the subjective sense of time, existentiality, irrationality and associativity of thinking, philosophy, the use of synaesthetic images, etc. Yu. Andrukhovych, O. Irvanets and V. Neborak used techniques characteristic of postmodern literature (intertextuality, allegory, allusion, grotesque, carnivalisation, etc.). The mythologem of the Moon in the artistic world of their poetry undergoes occasionally paradoxical metamorphoses, which are not found in the history of its interpretation by Ukrainian writers.

We consider the mythopoetic analysis of other symbolic images in the works of Yu. Andrukhovych, O. Irvanets and V. Neborak to be a prospect for further research. Such an approach will create a holistic view of the world-view and mythopoetic picture of the world of artists.

\section{References}

Andrukhovich, Yu. (1991). Exotic Birds and Plants: Poetry. Kyiv: Molod.

Anisimova, N. (2012). At the Change of Cultural Epochs: Poetry of the 80s of the Twentieth Century in the System of Late Ukrainian Modernism. A monograph. Berdyansk. Publisher: O.V. Tkachuk

Filonenko, N. (2007). Bu-Ba-Bu group as a phenomenon of the Ukrainian literary process of the late twentieth century: author's abstract dissertation. Kharkiv.

Meletynsky, E. (1998). Mythology. Large Encyclopedic Dictionary Moscow: Great Russian Encyclopedia

Irvanets, O. (1991). Irvanets, Tin'velykoho klasyka'ta inshi virshi, (Shadow of the Great Classicist and Other Poems): Poems Kyiv: Molod.

Eliade, M. (1996). Aspects of the Myth. Moscow: Invest-PPP, ST PPP.

Bagniuk, A. (2010). Symbols of Ukrainian Ideals. Ternopil: Navchalna Knyha-Bohdan.

Neborak, V. (1987). Amber Time: Poetry. Lviv: Kamenyar.

Bashlyar, H. (2004). Favourites: Poetics of Space. Moscow: Russian Political Encyclopedia.

Lévi-Strauss, C. (2000). Structural Anthropology. Kyiv : Osnovy.

O'Connell, M., Airey, R. (2009). Signs and Symbols: Illustrated Encyclopedia. Moscow: Exmo. 